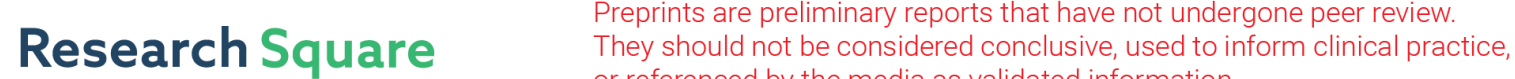 or referenced by the media as validated information. \\ Challenges and Opportunities of Laboratory diagnosis of Dengue virus infection: a review
}

Gaspary Oigen Mwanyika ( $\square$ gaspary.mwanyika@sacids.org)

Sokoine University of Agriculture https://orcid.org/0000-0001-5549-8393

\section{Gerald Misinzo}

Sokoine University of Agriculture

\section{Sima Rugarabamu}

Sokoine University of Agriculture

\section{Calvin Sindato}

National Institute for Medical Research

\section{Leonard Mboera}

SACIDS Foundation for One Health-Africa Centre of Excellence of Infectious Diseases of Humans and Animals

\section{Research article}

Keywords: Dengue infection, laboratory diagnoses, challenges, opportunities

Posted Date: April 17th, 2019

DOI: https://doi.org/10.21203/rs.2.9213/v1

License: (c) (i) This work is licensed under a Creative Commons Attribution 4.0 International License.

Read Full License 


\section{Abstract}

Background: Globally, dengue is one of the most important mosquito-borne viral diseases. Lack of effective vaccines and specific therapy against the disease threaten global health. Reliance on clinical diagnosis is complex due to clinical manifestations which resemble other diseases. This review examined various challenges of current dengue laboratory diagnoses, emerging technological opportunities and highlights considerations for future dengue diagnoses. Methods: A literature search from PubMed, Web of Science and Google Scholar databases was done from October 2018 to January 2019. Thematic descriptive analysis was done for all qualitative data and quantitative data analysis for computation of sensitivity and specificity of selected diagnostic tests at $95 \%$ confidence was done using $\mathrm{R}$ software (v3.4.4, mada package). The results: A total of 128 articles was reviewed. The current dengue laboratory diagnoses include (i) virus isolation (ii) detection of nucleic acid (iii) detection of non-structural protein 1(NS1) antigen and (iv) detection of anti-dengue antibodies. Assessment of diagnostic performance shows that reverse transcription-polymerase chain reaction (RT-PCR) and IgM antibody capture enzyme-linked immunosorbent assay (IgM ELISA) have high and consistent sensitivity ( $82.6 \%$ to $99.2 \%$ and $92.8 \%$ to $97.8 \%$, respectively) and specificity (78.8\% to $100 \%$ and $80.3 \%$ to $99 \%$, respectively) compared to NS1 ELISA and NS1 commercial rapid tests with sensitivity (53.7\% to $96.2 \%$ and $49.7 \%$ to $99.5 \%$, respectively) and specificity (34.5\% to $93.8 \%$ and $63.8 \%$ to $98.6 \%$, respectively). Major challenges

of dengue laboratory diagnosis include lack of reliable tests for routine purposes. Routine dengue tests are mainly serological, which are not suitable for discriminating dengue virus from other infecting flaviviruses due to cross-reactivity, narrow window of diagnosis due to short virus life cycle and inconsistent performance of commercial rapid tests. New technologies such as biosensors and nanobodies are being developed to improve sensitivity, specificity, detection time and reduce the cost. However, the performance of these new tools under field condition is unknown. Conclusion: Currently, RTPCR and IgM ELISA are the most sensitive and specific dengue diagnostic tests, despite their limitations. Future research should explore emerging technologies to improve the sensitivity and specificity of dengue diagnostics.

\section{Background}

Dengue is the most important mosquito-borne viral disease in the world. It is an acute disease caused by an RNA virus of the family Flaviviridae. The disease is transmitted between humans by Aedes mosquitoes mostly Ae. aegypti and Ae. albopictus. There are five dengue virus serotypes (DENV-1, DENV2, DENV-3, DENV-4, and DENV-5) and all cause a range of clinical manifestations from mild fever to severe infections [4]. Dengue is characterized by flu-like infection and affects individuals of all age groups [6]. Its peak of transmission has been observed during the rainy season [7]. Severe cases are presented with hemorrhage and organs impairment [58]. Diseases with similar clinical manifestations that should be considered in the differential diagnosis include influenza, measles, chikungunya, zika, rubella, rotavirus, malaria and typhoid infections. 
Over the past 50 years, dengue has spread worldwide with a 30 -fold rise in incidence rate [1]. It is estimated that 390 million cases of dengue occur each year with 96 million cases developing clinical manifestations that attribute to 20,000 deaths $[2,3]$. The disease is endemic in tropical and subtropical regions of Asia, Africa, and America and its burden has greatly increased over the past two decades. It is estimated that 3.9 billion people in more than 128 countries in the world are at risk of the dengue [13, 14]. WHO estimates that 50-100 million people are infected by dengue virus each year which results in 500,000 hospitalizations with a case fatality rate of $1 \%$ to $4 \%$ [15]. Though the actual burden of dengue is not well known in many countries, it is estimated that the incidence of dengue ranges from $6-29 \%$ per year [16]. Data from global electronic reporting system for disease outbreaks (ProMED-mail) [17] and WHO disease outbreak news (DONs) [18] indicates that the burden of dengue cases is high in South East Asia and America. Data (not shown) reported between 2008-2018 shows that a large number of dengue cases (> 200,000) was reported in five countries; Sri Lanka, Malaysia, Colombia, Brazil and Paraguay (Figure 1). The current global burden of dengue has been estimated to be 15.8 disability-adjusted lifeyears (DALYs) per 100,000 person-years [19].

Dengue is associated with significant health and economic impact in endemic settings [20,21]. However, poor surveillance and low diagnostic capacity of dengue in low and middle-income countries pose a significant diagnostic challenge [22, 23]. Moreover, lack of a licensed effective vaccine and specific therapeutics against dengue, leave early diagnosis and vector control as the only available intervention strategies [24, 25], which incidentally have not stopped its rapid emergence, re-emergence, and spread. In order to reduce high morbidity and mortality rates due to dengue, several diagnostic methods have been developed. These include dengue virus isolation in mosquito and mammalian cells, detection of dengue virus nucleic acids and/or antigens and detection of anti-dengue IgM and IgG antibodies [10,11]. Each of these diagnostic approaches exhibits several challenges that limit their utility and effectiveness for diagnosis of dengue virus infection. Detection of ribonucleic acid (RNA) by nucleic acid amplification method such as reverse transcription polymerase chain reaction (RT-PCR) is preferable for early diagnosis of dengue virus infection because it is relatively speedy and exhibits good sensitivity and specificity [12]. Nevertheless, the RT-PCR method requires serum samples collected within the first five days of infection, high-cost reagents, laboratory facilities and technical training [10]. This review examined various challenges of current dengue laboratory diagnoses, emerging technological opportunities and highlights considerations for future dengue diagnostics.

\section{Methods}

\section{Search strategy and selection process}

A literature search of published articles was done in PubMed, Web of Science, and Google Scholar databases from October 2018 to January 2019. The following key terms Dengue, dengue virus, dengue fever, diagnosis, reverse transcription polymerase chain reaction, real-time reverse transcription 
polymerase chain reaction, immunoglobulin $\mathrm{M}$, immunoglobulin $\mathrm{G}$, non-structural protein 1 , enzymelinked immunosorbent assay, rapid diagnostic test, virus isolation, hemagglutination inhibition tests, immunohistochemistry, and emerging diagnostic technologies were used to identify relevant articles. An example of search strategy for PubMed database is provided as supplementary material (S2). Additional data and grey literature were collected from the World Health Organization (WHO), ProMED-mail and Google electronic sources. Our inclusion criteria were the articles published in English describing the diagnostic options for dengue without restriction to geographical scale, study design or study population. As our interest was on emerging laboratory diagnostic innovations, only the articles published recently within the past 10 years (2008 to 2018) were included in the study. We aimed to include mainly studies describing the detection of non-structural protein-1 (NS1) antigen, Immunoglobulin M (IgM) and G (IgG) antibodies against dengue virus, reverse-transcription polymerase chain reaction (RT-PCR) and/or virus isolation/culture. In the selection process, titles and abstracts were initially examined against the inclusion criteria, followed by full-text examination using pre-designed data extraction form built in the spread sheet (Excel 2010, Microsoft Corp., and Redmond, WA, USA). The articles with any of these terms were considered for further evaluation and data extraction described in the subsequent section. Back referencing of included articles were examined as the potential sources of additional articles. The articles identified from search databases were finally exported to Rayyan QCRI application software for duplicate removal, screening of titles/abstracts and eligibility assessment [8] according to predefined inclusion/exclusion criteria.

\section{Data extraction}

Data for eligible studies were extracted into spreadsheet (MS-Excel 2010, Microsoft Corp., and Redmond, WA, USA) by one author and revised independently by another author. The following data; The author/year of publication, study design, evaluated test, reference standard, sample size, absolute true positive (TP), false negative (FN), false positive (FP) and true negative (TN) values were extracted from selected original studies reported between 2008 and 2018. This period was selected because the majority of studies that evaluated dengue diagnostic tests were reported and attempt to account for recent/emerging innovation in the disease diagnoses. Another data on author/year of publication, technology, biomarker, sample type, limit of detection, reference standard and the proposed application was extracted for review of emerging diagnostic technologies for dengue virus infection.

\section{Data analysis}

Thematic descriptive analysis and synthesis were performed for all qualitative data and quantitative data analysis to compute sensitivity and specificity of selected diagnostic tests at $95 \%$ confidence interval were done in R software ( $v$ 3.4.4, mada package, and primary function madad). 


\section{Results}

\section{Search results and characteristics of selected studies}

Assessment of full-text articles identified 128 articles for inclusion in the review. Of which 100 articles $(78.1 \%)$ were included in the thematic qualitative synthesis of the main review body and $28(21.9 \%)$ articles represented original studies selected for evaluation of sensitivity and specificity from 10 prospective and 18 retrospective studies. In the prospective studies, the diagnostic performance of reverse transcription polymerase chain reaction (RT-PCR) was evaluated in three studies ( $n=242$ sera), non-structural protein 1 enzyme-linked immunosorbent assay (NS1 ELISA) in four studies ( $n=544$ sera), non-structural protein 1 rapid test (NS1 RDT) in two studies ( $n=174$ sera) and IgM antibody capture enzyme-linked immunosorbent assay (IgM ELISA) in one study ( $n=863$ sera). On the other hand, the retrospective studies evaluated the performance of RT-PCR in eight studies ( $n=1365$ sera), NS1 ELISA in two studies ( $n=1291$ sera), NS1 RDT in four studies ( $n=904$ sera), IgM ELISA in two studies $(n=1324$ sera) and IgM RDT in two studies ( $n=724$ sera). The search and selection process of articles included in the review is presented by PRISMA flow diagram in Figure 2.

\section{Dengue laboratory diagnoses}

Results from the literature search identified 51 articles which described 13 different laboratory diagnostic options for dengue virus infection namely, virus isolation (2), reverse transcription polymerase chain reaction ( $R T$-PCR, $n=16)$, reverse transcription loop-mediated isothermal amplification (RT-LAMP, $n=2$ ), nucleic acid sequence-based amplification (NASBA, $n=2$ ), Reverse transcription recombinase polymerase amplification (RT-RPA, $n=1$ ), non-structural protein 1 enzyme-linked immunosorbent assay (NS1 ELISA, $n=9)$, non-structural protein 1 rapid test (NS1 RDT, n=6), IgM antibody capture enzyme-linked immunosorbent assay (IgM ELISA, $n=4)$, IgG antibody capture enzyme-linked immunosorbent assay (IgG ELISA, $n=2)$, IgM/lgG seroconversion $(n=2)$, Haemagglutination inhibition test $(n=1)$, Plaque reduction neutralization test (PRNT, $n=2)$ and immunohistochemistry $(n=2)$ as shown in Table 1. The main advantages and limitations of each method are described in the subsequent section.

\section{Diagnostic sensitivity and specificity}

The absolute values of true positive, false positive, false negative and true negative were extracted from original studies for computation of sensitivity and specificity of dengue diagnostic tests were available for reverse transcription polymerase chain reaction (RT-PCR, $n=11$ studies), non-structural protein 1 enzyme-linked immunosorbent assay (NS1 ELISA, $n=6$ studies), non-structural protein 1 rapid test (NS1 $\mathrm{RDT}, \mathrm{n}=6$ studies), IgM antibody capture enzyme-linked immunosorbent assay (IgM ELISA, $\mathrm{n}=2$ studies) and IgM rapid diagnostic tests (IgM RDT, $n=2$ studies as indicated in Table 2. The results showed that the sensitivity of RT-PCR and IgM ELISA ranged from $82.6 \%$ to $99.2 \%$ against $92.8 \%$ to $97.8 \%$, respectively. On the other hand, specificity ranged from $78.8 \%$ to $100 \%$ against $80.3 \%$ to $99 \%$, respectively and sensitivity and specificity of NS1 ELISA and NS1 RDT ranged from $53.7 \%$ to $96.2 \%$ against $49.7 \%$ to $99.5 \%$ and from 
$34.5 \%$ to $93.8 \%$ against $63.8 \%$ to $98.6 \%$, respectively. For IgM rapid test, sensitivity and specificity ranged from $30 \%$ to $92.8 \%$ and $87.6 \%$ to $97.8 \%$ respectively.

\section{Emerging diagnostic technologies}

Our literature search focused on four technologies namely biosensors, microarrays, microfluidics and nanobodies whose diagnostic potential for various infectious diseases has recently gained the attention of researchers across the globe. The search results identified 10 studies that demonstrated the potential use of biosensors ( $n=5$ studies), microarray ( $n=3$ studies) and microfluidics ( $n=2$ studies) in the diagnosis of dengue virus infection as shown in Table 3. Further, the usefulness of nanobodies as diagnostic tools for dengue virus infection has also been demonstrated in several studies discussed in the subsequent section.

\section{Discussion}

This review describes the utility and limitations of current dengue laboratory diagnostic options that range from the isolation of the whole virus, detection of viral components (nucleic acid and antigens) to quantification of host immune response using anti-dengue antibodies. In addition, various challenges and future perspectives in dengue virus diagnosis have been stated.

\section{Current dengue virus laboratory diagnoses}

Early and accurate laboratory diagnosis of dengue is critical for its appropriate management. According to World Health Organization dengue guidelines for diagnosis, treatment, prevention and control [60], several laboratory diagnostic options exist namely; i) Isolation and identification of dengue virus, ii) Detection of dengue nucleic acid (RNA), iii) Detection of dengue non-structural protein 1 antigens (NS1), iv) Detection of anti-dengue immunoglobulin $M$ and $G$ antibodies, and v) Detection of dengue inhibiting and/or neutralizing antibodies (Table 1). The appropriate use of each method largely depends on the timing of sample collection due to the kinetics of diagnostic biomarkers during the course of dengue virus infection. Improperly collected serum samples can affect the sensitivity of the tests because detection of virus or its components (RNA or antigen) for early case identification requires acute sera collected within five days of infection when the viral load is high [24]. After this period, viral load diminishes due to clearance of viruses from the blood circulation followed by generation of anti-dengue antibodies with IgM antibodies expressed much earlier during the first exposure and IgG following subsequent infection $[25,26]$.

\section{Isolation and identification of dengue virus}

Dengue viruses are isolated from clinical samples (serum or plasma) collected during the acute phase of infection in mosquito cells, mostly C6/36 (Ae. albopictus clone) and AP-61 (Ae. pseudoscutellaris) or mammalian cells mostly, Vero (African green monkey kidney), Limited Liability Company Rhesus Monkey Kidney (LLC-MK2) and Baby hamster kidney (BHK-21) [12, 29]. In addition, the viruses can be isolated by 
inoculating into mouse brain [30], followed by identification using indirect immunofluorescence assay (IFA) [31]. Virus isolation method requires Biosafety level-3 facilities, cell culture skills, high maintenance costs and may take 7 days for the results to be given $[12,27]$.

\section{Detection of dengue virus nucleic acid}

\section{Polymerase chain reaction (PCR) methods}

Detection of dengue virus ribonucleic acid (RNA) in serum or plasma samples of infected individuals is performed by conventional reverse transcription polymerase chain reaction (RT-PCR) using synthetic primers, random hexamers (N) 6 or oligo (dT)15-18 or oligo (dT)15-23 that anneal to specific regions of target RNA transcripts [32]. RT-PCR methods are more sensitive and faster than the culture method [24]. However, in order to improve the sensitivity and specificity of conventional RT-PCR, nested RT-PCR and real-time RT-PCR were developed. Nested RT-PCR prevents non-specific binding of primer-dimer products that can be developed in a single-step standard RT-PCR. Nested RT-PCR involves two rounds of PCR, in the first PCR the products are generated using universal dengue primers that act as templates for the second PCR. In the second PCR, shorter, but more specific products are generated using dengue virus serotype-specific oligonucleotides that target different regions of virus genome such as envelope and non-structural protein 1 within the products of first PCR primers [34]. In real time RT-PCR, dengue virus RNA is detected using a pair of serotype-specific primers and fluorescent probes such as TaqMan and SYBR green $[35,36]$. Unlike the culture method, RT-PCR has an extended window period of diagnosis when urine and/or saliva samples are used instead of sera $[37,38]$. Despite the advantages of RT-PCR, this method requires expensive reagents and equipment, specialized laboratory infrastructures and staff training [10].

\section{Non-PCR nucleic acid amplification methods}

Non-PCR based methods are yet to be approved by the World Health Organization. However, their diagnostic potential for dengue virus infection has been appreciated in several studies $[40,41]$. The methods do not require conventional thermocycling amplification but use constant temperatures to amplify target dengue ribonucleic acid (RNA). Non-PCR methods reported in the literature include reverse transcription loop-mediated isothermal amplification (RT-LAMP) that uses a single enzyme with high strand displacement activity such as Bacillus subtilis deoxyribonucleic acid (DNA) polymerase and four sets of viral specific primers that identify six regions of the target complementary DNA (cDNA) and the results can be visualized by naked eyes [42,43]. Another method is nucleic acid sequence-based amplification (NASBA). The method detects target dengue RNA using three enzymes reverse transcriptase, RNase $\mathrm{H}$ and T7 DNA dependent RNA polymerase [44, 45]. Reverse transcription recombinase polymerase amplification (RT-RPA) is another method that uses recombinase primers to scan double-stranded DNA and facilitate strand exchange at the target regions without the need for primer melting temperatures [46]. The utility of RT-RPA in the diagnosis of dengue infection has been reported by several authors $[47,45]$. 


\section{Detection of dengue non-structural protein 1}

Non-structural protein 1 (NS1) is a glycoprotein highly conserved in dengue viruses and other flaviviruses and it is expressed in either membrane-associated or secreted forms $[49,51]$. During the early phase of infection, NS1 proteins are secreted abundantly by infected host cells into the blood circulation that can be detected by enzyme-linked immunosorbent assay (NS1 ELISA) or rapid diagnostic tests (NS1 RDTs) $[48,54]$. The NS1 proteins can be detected by up to 9 days post-infection and extend the window period of diagnosis when compared to culture and RT-PCR methods [51,52]. However, the level of detectable NS1 antigens diminishes during secondary infection due to complexing with anti-NS1 antibodies formed during the past infection [26]. The limitations of NS1 antigen capture tests include its requirement of Biosafety level-3 facilities, inability to discriminate between dengue virus serotypes and low sensitivity in secondary infection has been reported [53].

\section{Detection of anti-dengue antibodies}

Anti-dengue antibodies are initially detectable 3-5 days post infection. During this period, anti-dengue immunoglobulin M (IgM antibodies) can be detected by enzyme-linked immunosorbent assay (ELISA) in $50 \%$ of infected individuals and over $90 \%$ after 10 days of illness. The IgM antibodies are expressed much earlier than immunoglobulin $\mathrm{G}$ (IgG antibodies) during primary dengue virus infection that indicates recent dengue infection. The key challenge of diagnostic IgM antibodies is the persistence in circulation up to 90 days that limits the ability to differentiate recent dengue virus infection from past flavivirus exposure $[28,54]$.

The IgG antibodies develop a few days later during primary infection and are detectable 10 days postinfection by ELISA. IgG antibodies can last for life in the blood circulation [55]. Thus, the detection of IgG antibodies indicates past dengue infection or previous flavivirus exposure [56,57]. The IgM and IgG titer levels depend on the state of dengue infection. During primary infection, IgM titres are high and more specific compared to secondary infection, conversely, IgG titers are high during secondary infection compared to primary infection $[10,58]$. Furthermore, IgM: IgG ratio can be used to differentiate primary and secondary dengue infection. High IgM:IgG optical density ratio $(O D>1.2$ in 1: 100 dilution or 1.4 in 1:20 dilution) shows primary infection, while $O D<1.2$ or 1.4 is an indication of secondary infection [59, 60]. The confirmation of anti-dengue antibodies requires the quantification of a 4-fold rise of anti-dengue IgG antibody titer between convalescent and acute phase sera or the detection of dengue-specific lgM antibodies [61]. The main limitation of ELISA is cross-reactivity to pre-existing antibodies expressed during the previous infection that contributes to false positive results [10]. Other limitations include the need for paired serum samples and low IgM antibody levels during secondary infection [11, 54].

\section{Detection of dengue virus inhibiting antibodies}


Haemagglutination inhibition test $(\mathrm{HI})$ is used to measure the presence of anti-dengue antibodies in the sera through agglutination reaction. Agglutination is caused by the ability of dengue virus antigens to clump with certain types of red blood cells (RBCs). When sufficient anti-dengue antibodies are present in the sera of an infected individual, agglutination of RBCs by dengue antigens is impeded [62]. The main disadvantages of this test include cross-reactivity to antibodies of other flaviviruses, poor sensitivity and require paired sera for confirmation $[63,64]$.

\section{Detection of dengue virus neutralizing antibodies}

The detection of dengue virus neutralizing antibodies in sera of infected individuals is performed by plaque reduction and neutralization test (PRNT). In PRNT, neutralizing antibodies present in the sera of infected individuals inactivate dengue viruses and block their replication inside the target cells such as Vero and BHK21 $[65,66]$. The Positive sera are determined by a $50 \%$ reduction or more of viral particles known as plaque forming units (PFU). PRNT is expensive, lacks standardization method, requires cell culture skills, Biosafety level 3 facilities and it is time-consuming $[66,67]$.

\section{Immunohistochemistry}

The detection of dengue antigens in the infected tissues such as a biopsy is performed by immunohistochemical techniques (IHC). The tissues are fixed in formalin and embedded in paraffin followed by detection of viral antigens by indirect fluorescent antibody staining or immunoalkaline phosphatase. The results of immunohistochemistry can be visualized by a fluorescence microscope [61, 62]. This technique is less sensitive compared to culture and RT-PCR, can cause cross-reactivity and requires some expertise in pathology $[63,64]$.

\section{Evaluation of sensitivity and specificity}

The performance of diagnostic tests is important for the accurate diagnosis of dengue infection. Yet, comparison of test performance remains a challenge due to various factors such as the existence of multiple evaluation methods, the timing of sample collection (acute, late acute or convalescent sera) can impact the use/or sensitivity of particular test at different phases of infection [28].

We computed sensitivity and specificity of RT-PCR [33, 35, 68-76], NS1 ELISA [75-80], NS1 rapid diagnostic tests [81-86], IgM ELISA $[87,89,90]$ and IgM RDT $[88,91]$ based on absolute true positive, false positive, false negative and true negative values from selected original studies reported between 2008 and 2017. The overall results from 28 studies show that RT-PCR and IgM ELISA methods have good and consistent diagnostic performance across various studies with an overall sensitivity $(82.6-99.2 \%, 95 \% \mathrm{Cl}$ against $92.8-97.8 \%, 95 \% \mathrm{Cl}$, respectively) and specificity range $(78.8-100 \%, 95 \% \mathrm{Cl}$ against $80.3-99 \%$, $95 \% \mathrm{Cl}$. These observations concur with the results reported earlier [94]. On the other hand, the variable performance of various NS1 antigen detection tests was observed for both sensitivity (49.7\% to 99.5\%) and specificity $(34.5 \%$ to $98.6 \%)$. Similar findings were reported previously by others $[28,89,94,95]$. The 
observed inconsistent sensitivity and specificity of NS1 antigen tests can be presumably associated with a small number of studies $(n=12)$ that evaluated commercial NS1 antigen tests (Table 2); poor quality of preserved sera tested in 6 retrospective studies $[81,82,83,84,86$ and 88$]$ and difference in the quality of NS1 antigens among manufacturers [28]. The performance of immunoglobulin M rapid diagnostic test (IgM RDT) was not evaluated due to inadequate data. Only two studies reported the diagnosis of dengue virus infection using IgM rapid test [90, 93]. Generally, our findings suggest that, RT-PCR and IgM-ELISA show good sensitivity and specificity for dengue virus infection compared to NS1 antigen tests despite the limitations.

\section{Emerging diagnostic technologies for dengue virus infection}

In recent years, advances in technologies have been made with a view to providing solutions for existing diagnostic challenges of dengue virus infections. In the current review, we describe the potential diagnostic applications of new technologies based on biosensors, microarrays, microfluidics, and nanobodies. The utility of several emerging technologies has been reported previously $[98,99]$. We highlight the diagnostic opportunities for dengue virus infection emanating from biosensor, microarray and microfluidic-based technologies. In the literature search, we observed that several emerging diagnostic platforms can use a wide range of diagnostic signatures for dengue virus such as complementary DNA, non-structural protein 1 (NS1), envelope domain-III (EDIII) and immunoglobulin M antibody (Table 3). All these signatures can be used as biomarkers for acute-phase dengue virus infection and facilitate the early identification of dengue-infected individuals which is crucial for infection control and clinical management (Ref). In addition, it has been demonstrated that clinical samples other than blood such as saliva and urine can be used as diagnostic specimens for acute or late-stage dengue virus infection $[104,106]$ and this can extend the narrow window period of dengue diagnosis due to low viral load after viremic phase of infection [28]. Moreover, it has been shown that several emerging diagnostic platforms can be tailored for the simultaneous detection of multiple dengue virus serotypes in a single assay (multiplex) and used at the point of care (POC) for rapid detection of dengue cases that would be vital during outbreaks (Table 3). Thus, the potential of biosensors, microarrays, microfluidics, and nanobdies technologies in the diagnosis of dengue virus infection has been examined.

Biosensors. Biosensors use bioreceptors to recognize and interact with target analytes such as viral nucleic acids, antigens or antibodies and generate specific signals which are received by transducers processed and finally detected [96, 97]. Biosensors utilize different mechanisms namely, electrochemical, optical or piezoelectric transduction and surface plasmon resonance (SPR) to detect viral pathogens [98100]. Application of biosensors to detect dengue virus has been reported in several studies [101-105]. In those studies, a range of biosensor-based diagnostic technologies like surface plasmon resonance (SPR) to detect dengue viruses in the serum, saliva and urine samples using different biomarkers complementary DNA (cDNA), IgM antibody and non-structural protein 1 (NS1) antigen was demonstrated with the promising limit of detections as shown in Table 3. 
Microarrays: The microarrays or microchips use specific probes printed on the solid surfaces usually glass or silicon membranes to allow the simultaneous identification of multiple pathogen targets such as nucleic acids, proteins or enzymes [106, 107]. Application of microarray platforms in the diagnosis of dengue infection has been reported in several studies. Bumgarner and others demonstrated the simultaneous detection of dengue virus serotypes (DENV-1, DENV-2, DENV-3, and DENV-4) using complementary DNA based microarray [108]. Another study by Cretch et al (2014) showed the detection of anti-dengue immunoglobulin $\mathrm{M}$ antibodies using single-molecule array [109] and envelope domain III (EDIII) enzyme-linked immunosorbent assay-based array with an improved limit of detection compared to conventional IgM antibody capture enzyme-linked immunosorbent assay [110].

Microfluidic and Lab-on-a-chip platforms: The microfluidic platforms are automated devices which use microchannels to process small volume samples in microlitres $(\mu \mathrm{L})$, nanolitres $(\mathrm{nL})$ or picolitres $(\mathrm{pL})$ whereas lab-on-a-chips (LOCs) are microchips which integrate microfluidic technology to perform the separation and detection of target analytes. The integration of microfluidic and LOCs reduces detection time and cost $[111,112]$. The use of microfluidics to detect dengue virus in cell lysates and serum samples has been reported by several authors with a promising limit of detection [113, 114].

Nanobodies. Nanobodies are single domain antigen binding fragments of camelid heavy chain only antibodies (HCAbs). The HCAbs are unique immunoglobulin $\mathrm{G}$ isotypes devoid of light chains (VL and $\mathrm{CL}$ ) and the first constant region (CH1). These unique antibodies are found in the sera of camelids such as Alpaca, Ilamas, and vicugna, but also in certain cartilaginous fish such as sharks $[115,116]$.

The nanobodies exhibit unique features that surpass that of conventional monoclonal antibodies and recombinant antigen-binding fragments. These features include: (i) Small in size (4 $2.5 \mathrm{~nm})$,(ii) High sensitivity, specificity and affinity to a diverse of cognate antigens (iii) Low molecular weight ( $15 \mathrm{kDa}$ ) compared to large classical antibody binding fragments such as fragment antigen binding (Fab 55kDa) and single chain variable fragment ( $\mathrm{scFv} \sim 28$ ), (iv) Originate from single variable (V), diversity (D) and joining $(\mathrm{J})$ exon located in $\mathrm{H}$ locus of camelid genome that encodes nanobody genes (VHHs, $450 \mathrm{bp}$ ) without post-transcriptional process. Presence of single V(D)J exon makes genetic manipulation of VHHs in simple bacteria cells like Escherichia coli easy and cost-effective [117], (v) Prolate surfaces that expand recognition of hidden epitopes that cannot be accessed by traditional antibodies, (vi) Highly variable complementary determining region 1 (CDR1) and elongated complementary determining region 3 (CDR3) loops due to non-templated nucleotide insertions. The long CDR3 increases recognition repertoire of cognate antigens [118, 119], (vii) High solubility due to hydrophilic amino-acid substitutions at four Kabat positions;37 (valine to phenylalanine), 44 (glycine to glutamine), 45 (leucine to arginine) and 47 (tryptophan to glycine) in framework region 2 to replace the classical hydrophobic interface of conventional antibodies [120,121], (viii) High thermal stability at elevated temperatures up to $90^{\circ} \mathrm{C}$ and tolerant to extreme $\mathrm{pH}$ and chemicals $[122,123]$. These features brand nanobodies as attractive reagents for future dengue-specific immunodiagnostics. 
The diagnostic potential of nanobodies for different infectious diseases has been reported by several authors $[124,125]$. For dengue infection, Fatima et al (2014) demonstrated the detection of dengue nonstructural protein 1 (NS1) antigens using nanobodies with better sensitivity and specificity compared to conventional monoclonal antibodies [126]. Most recently, Shriver-Lake et al (2017) [127] have revealed good sensitivity of a sandwich ELISA using NS1-specific nanobodies targeting four dengue virus serotypes (DENV-1, DENV-2, DENV-3, and DENV-4) without cross-reactivity to close related flaviviruses.

\section{Challenges in dengue virus diagnosis}

The findings from literature showed that the main challenges in laboratory diagnostic techniques for dengue include (i) unreliable routine diagnostic tests, (ii) narrow window period of diagnosis, and (iii) poor sensitivity and specificity of commercial rapid tests. The availability of more reliable diagnostic tests for routine diagnosis of dengue virus infection remains a challenge. Routine laboratory diagnosis of dengue virus infection is based on serological tests like IgM antibody capture enzyme-linked immunosorbent assay (IgM ELISA). These tests are not very specific for infecting dengue virus due to cross-reactivity with antibodies from previous flavivirus exposure or vaccination [24]. Moreover, serological tests require late acute or convalescent sera collected 3-5 days post infection. Convalescent sera are not suitable for confirmation of recent dengue virus infection because anti-dengue antibodies expressed during this period can persist in the blood circulation for several months $[10,11]$. Thus, it is problematic to distinguish recent from past dengue virus infection due to cross-reactivity with pre-existing antibodies.

The use of more reliable tests like reverse transcription polymerase chain reaction (RT-PCR) which is considered more sensitive and specific for acute-phase dengue virus infection than non-structural protein 1 detection tests (NS1) is limited in developing countries due to high-cost reagents, specialized equipment, laboratory infrastructures, maintenance, and personnel training which undermine its utility for routine purposes.. In order to complement the use of expensive RT-PCR, NS1 capture ELISA and rapid tests were developed. Nevertheless, NS1 ELISA exhibit low sensitivity in secondary dengue infection due to complexing with anti-NS1 antibodies generated during the past infection. Further, NS1 antigen tests show poor specificity due to cross-reactivity with antibodies from close related flaviviruses such as Zika and Yellow fever. More further, NS1 antigen test kits are not commercially available for all flaviviruses that make the discrimination of dengue virus and other co-circulating flaviviruses difficult [128]. Other limitations of NS1 antigen tests include the inability to differentiate between dengue virus serotypes [26]. Secondary infection with a different serotype often leads to a more severe disease due to antibodydependent enhancement ( $A D E)$. In $A D E$, cross-reactive antibodies produced by previous heterologous 
serotype facilitates the replication of a different infecting dengue subtype within the macrophages and increases the chance of developing a more severe form of the disease [128].

Moreover, a narrow window period of diagnosis due to a short life cycle of dengue virus makes the confirmation of acute-phase dengue virus infection challenging due to the timing of sample collection. Diagnosis of acute-phase infection must be performed within the first five days of virus infection, beyond this period the sensitivity of genomic-based tests like RT-PCR declines due to low viral load [27, 28].

Also, low and variable sensitivity and specificity of existing commercial rapid diagnostic tests (RDTs) due to the poor quality of antigens among manufacturers have been reported [28, 94]. As a consequence, confirmation of dengue infection by rapid tests alone can be inaccurate and may require dual confirmation with reference standards that adds cost per sample.

\section{Future considerations}

In order to address the current diagnostic challenges of dengue virus infection reported in various studies, we promote the need to improve sensitivity and specificity of commercial rapid tests for dengue, and evaluation of the diagnostic performance of emerging diagnostic tools under field condition. We also recommend the development of new tools to detect both asymptomatic and acute-phase dengue virus infection in order to limit on-going virus transmission and facilitate the provision of appropriate patient care. Early detection and discrimination of dengue virus infection from other emerging virus infections such as Zika, and Chikungunya remains a challenge. Dengue, Zika, and Chikungunya virus co-infections are increasingly been reported and have significant clinical implication for patient care $[9,22,23]$ Thus, the development of robust, simple and cost-effective diagnostic tools for the simultaneous detection of Dengue, Zika and Chikungunya at the point of care remains an important facet of future diagnostics.

\section{Conclusions}

Early and accurate laboratory diagnosis of dengue virus infection remains vital for infection containment and clinical management. Reverse transcription polymerase chain reaction (RT-PCR) and IgM antibody capture enzyme-linked immunosorbent assay (IgM ELISA) present a good diagnostic performance compared to non-structural protein 1 antigen (NS1) tests in the diagnosis of dengue. The performance of emerging diagnostic platforms for dengue virus infection has not been evaluated under the field conditions. There is a need to improve sensitivity and specificity of rapid diagnostic tests which is imperative for early diagnosis and prompt response during outbreaks and explore new avenues in technology that will help to enhance the diagnosis of dengue virus infection. 


\section{Abbreviations}

DENV, dengue virus; rRT-PCR, real time reverse transcription polymerase chain reaction; NS1, nonstructural protein 1; RDT, rapid diagnostic test; IgM, immunoglobulin M, ELISA, enzyme-linked immunosorbent assay; MAC; immunoglobulin M antibody capture; PRNT, plaque reduction neutralization test; SPR, surface plasmon resonance; EDIII, Dengue envelope domain III;LRSPP, long range surface plasmon polariton; DNA, Deoxyribose nucleic acid; cDNA, complementary DNA; NS1, non-structural protein 1; POC, point of care; NA, not applicable.

\section{Declarations}

\section{Ethical approval and consented to participate}

Not applicable

\section{Consent for publication}

Not applicable

\section{Availability of data and materials}

Contact the authors for addition information

\section{Competing interests}

The authors have declared no conflict of interests

\section{Funding}

This paper was part of the literature review as the basis for original research on the development of diagnostic tools for dengue virus infection which is supported by the Government of Tanzania (GOT) and the World Bank (WB) under WB-ACE II Grant PAD1436 through SACIDS Foundation for One Health. The authors declare that the funders did not support the design, data mining, analysis, interpretation, and publication of this review; the funds were allocated for the specialized training and laboratory experiments of the original research. 


\section{Authors' contributions}

GOM conceived the idea, performed a literature search, data extraction, analysis and drafted the first version of the manuscript. SR cleaned the data and revised the first version of the manuscript. GM, CS, and LM performed a compressive revision of the final draft manuscript. The final version of the manuscript was revised by all authors prior to submission.

\section{Acknowledgements}

We thank the Community of Practice members of Emerging and Vector-Borne Disease at the SACIDS Foundation for One Health for their enthusiasm and discussion throughout the review process.

\section{References}

1. Pang T, Mak TK, Gubler DJ. Prevention and control of dengue the light at the end of the tunnel. Lancet Infect Dis. 2017;17(3):e79-e87.

2. Bhatt S, Gething PW, Brady OJ, Messina JP, Farlow AW, Moyes CL, et al. The global distribution and burden of dengue. Nature. 2013;496(7446):504.

3. Murray NEA, Quam MB, Wilder-Smith A. Epidemiology of dengue: past, present and future prospects. Clin Epidemiol. 2013;5:299-309.

4. Mustafa, M. S., Rasotgi, V., Jain, S., and Gupta, V. Discovery of fifth serotype of dengue virus (DENV5): A new public health dilemma in dengue control. Med J Armed Forces India. 2015; 71(1): 67-70.

5. Murray NEA, Quam MB, Wilder-Smith A. Epidemiology of dengue: past, present and future prospects. Clin Epidemiol. 2013;5:299-309.

6. Thomas EA, John M, Bhatia A. Muco-Cutaneous manifstations of dengue viral infection in Punjab. Int J Dermatol. 2007;46:715-19.

7. Arshad I, Malik FA, Hussain A, Shah SA. Dengue fever: Clinico-pathologic correlations and their association with poor outcome. Professional Med J. 2011;18:57-63.

8. Ouzzani M. Rayyan - a web and mobile app for systematic reviews. Syst Rev. 2017;(2016):1-10.

9. Carrillo-Hernández MY, Ruiz-Saenz J, Villamizar LJ, Gómez-Rangel SY, Martínez-Gutierrez M. Cocirculation and simultaneous co-infection of dengue, chikungunya, and zika viruses in patients with febrile syndrome at the Colombian-Venezuelan border. BMC Infect Dis. 2018;18(1):61.

10. Muller DA, Depelsenaire ACl, Young PR. Clinical and Laboratory Diagnosis of Dengue Virus Infection. J Infect Dis. 2017;215(2):S89-95.

11. Peeling RW, Artsob H, Pelegrino JL, Buchy P, Cardosa MJ, Devi S, et al. Evaluation of diagnostic tests: dengue. Nat Rev Microbiol. 2010;8(12):S30-38.

12. Tang KF, Ooi EE. Diagnosis of dengue: an update. Expert Rev Anti Infect Ther. 2012;10(8):895-907. 
13. Murray NEA, Quam MB, Wilder-Smith A. Epidemiology of dengue: past, present and future prospects. Clin Epidemiol. 2013;5:299-309.

14. Brady OJ, Gething PW, Bhatt S, Messina JP, Brownstein JS, Hoen AG, et al. Refining the global spatial limits of dengue virus transmission by evidence-based consensus. PLoS Negl Trop Dis. 2012;6(8):e1760.

15. Wilder-Smith A, Byass P. The elusive global burden of dengue. Lancet Infect Dis. 2016;16(6):629-31.

16. Balmaseda A, Standish K, Mercado JC, Matute JC, Tellez Y, Saborío S, et al. Trends in patterns of dengue transmission over 4 years in a pediatric cohort study in Nicaragua. $J$ Infect Dis. 2010;201(1):5-14.

17. ProMED-mail. http://www.promedmail.org/. Accessed 22 Jan 2019.

18. WHO | Dengue fever. http://www.who.int/csr/don/archive/disease/dengue_fever/en/. Accessed 22 Jan 2019.

19. Stanaway JD, Shepard DS, Undurraga EA, Halasa YA, Coffeng LE, Brady OJ, et al. The global burden of dengue: an analysis from the Global Burden of Disease Study 2013. Lancet Infect Dis. 2016;16:712-23.

20. Shepard DS, Undurraga EA, Halasa YA. Economic and disease burden of dengue in Southeast Asia. PLoS Negl Trop Dis. 2013;7(2):e2055.

21. Jit M. The economic burden of dengue: no longer invisible or unavoidable. Lancet Infect Dis. 2016;16(8):873-4.

22. Furuya-Kanamori L, Liang S, Milinovich G, Magalhaes RJS, Clements AC, Hu W, et al. Co-distribution and co-infection of chikungunya and dengue viruses. BMC Infect Dis. 2016;16(1):84.

23. Martinez JD, Garza JAC la, Cuellar-Barboza A. Going Viral 2019: Zika, Chikungunya, and Dengue. Dermatol Clin. 2019;37(1):95-105.

24. Guzman MG, Harris E. Dengue. The Lancet. 2015;385(9966):453-465.

25. Dias CN, Moraes DFC. Essential oils and their compounds as Aedes aegypti L. (Diptera: Culicidae) larvicides: review. Parasitol Res. 2014;113(2):565-92.

26. Muller DA, Depelsenaire ACl, Young PR. Clinical and Laboratory Diagnosis of Dengue Virus Infection. J Infect Dis. 2017;215(2):S89-95.

27. Bhat VG, Chavan P, Ojha S, Nair PK. Challenges in the Laboratory Diagnosis and Management of Dengue Infections. Open Microbiol J. 2015;9:33-7.

28. Blacksell SD. Commercial dengue rapid diagnostic tests for point-of-care application: recent evaluations and future needs? J Biomed Biotechnol. 2012;2012:151967.

29. Igarashi A. Isolation of a sinch's Aedes albopictus cell clone sensitive to Dengue and Chikungunya viruses. J Gen Virol. 1978;40:531-44.

30. Meiklejohn G, England B, Lennette null. Propagation of dengue virus strains in unweaned mice. Am J Trop Med Hyg. 1952;1(1):51-8. 
31. Sucipto TH, Ahwanah NLF, Churrotin S, Matake N, Kotaki T, Soegijanto S. Immunofluorescence assay method to detect dengue virus in Paniai-Papua. AIP Conf Proc. 2016;1718(1):040001.

32. Bachman J. Reverse-transcription PCR (RT-PCR). Methods Enzymol. 2013;530:67-74.

33. Requena-Castro R, Reyes-López MÁ, Rodríguez-Reyna RE, Palma-Nicolás P, Bocanegra-García V. Molecular detection of mixed infections with multiple dengue virus serotypes in suspected dengue samples in Tamaulipas, Mexico. Mem Inst Oswaldo Cruz. 2017;112(7):520-2.

34. Lanciotti RS, Calisher CH, Gubler DJ, Chang G-J, Vorndam AV. Rapid detection and typing of dengue viruses from clinical samples by using reverse transcriptase-polymerase chain reaction. $\mathrm{J}$ Clin Microbiol. 1992;30(30):545-551.

35. Santiago GA, Vergne E, Quiles Y, Cosme J, Vazquez J, Medina JF, et al. Analytical and Clinical Performance of the CDC Real Time RT-PCR Assay for Detection and Typing of Dengue Virus. PLoS Negl Trop Dis. 2013;7(7):e2311.

36. Johnson BW, Russell BJ, Lanciotti RS, Icrobiol JCLINM. Serotype-Specific Detection of Dengue Viruses in a Fourplex Real-Time Reverse Transcriptase PCR Assay. N Y. 2005;43(10):4977-83.

37. Poloni TR, Oliveira AS, Alfonso HL, Galvão LR, Amarilla AA, Poloni DF, et al. Detection of dengue virus in saliva and urine by real time RT-PCR. Virol J. 2010;7:22.

38. Hirayama, T., Mizuno, Y., Takeshita, N., Kotaki, A., Tajima, S., Omatsu, T., Takasaki, T. Detection of dengue virus genome in urine by real-time reverse transcriptase PCR: A laboratory diagnostic method useful after disappearance of the genome in serum. J Clin Microbiol.2012; 50(6): 2047-2052.

39. Teoh B-T, Sam S-S, Tan K-K, Danlami MB, Shu M-H, Johari J, et al. Early detection of the dengue virus using reverse transcription-recombinase polymerase amplification. J Clin Microbiol. 2015;53(3):830837.

40. Neeraja M, Lakshmi V, Lavanya V, Priyanka EN, Parida MM, Dash PK, et al. Rapid detection and differentiation of dengue virus serotypes by NS1 specific reverse transcription loop-mediated isothermal amplification (RT-LAMP) assay in patients presenting to a tertiary care hospital in Hyderabad, India. J Virol Methods. 2015;211:22-31.

41. Sahni AK, Grover N, Sharma A, Khan ID, Kishore J. Reverse transcription loop-mediated isothermal amplification (RT-LAMP) for diagnosis of dengue. Med J Armed Forces India. 2013;69(3):246-253.

42. Tomita N, Mori Y, Kanda H, Notomi T. Loop-mediated isothermal amplification (LAMP) of gene sequences and simple visual detection of products. Nat Protoc. 2008;3(5):877-82.

43. Notomi T. Loop-mediated isothermal amplification of DNA. Nucleic Acids Res. 2000;28(12):63e - 63.

44. Deiman B, van Aarle P, Sillekens P. Characteristics and applications of nucleic acid sequence-based amplification (NASBA). Mol Biotechnol. 2002;20(12):163-79.

45. Wu SL, Lee EUNMI, Putvatana R, Shurtliff RN, Porter KR, Suharyono W, et al. Detection of Dengue Viral RNA Using a Nucleic Acid Sequence-Based Amplification Assay. J Clin Microbiol. 
2001;39(8):2794-8.

46. James A, Macdonald J. Recombinase polymerase amplification: emergence as a critical molecular technology for rapid, low-resource diagnostics. Expert Rev Mol Diagn. 2015;15(11):1475-1489.

47. El Wahed AA, Patel P, Faye $O$, Thaloengsok S, Heidenreich D, Matangkasombut P, et al. Recombinase polymerase amplification assay for rapid diagnostics of dengue infection. PloS One. 2015;10(6):e0129682.

48. Shrivastava, A., Dash, P., Tripathi, N., Sahni, A., Gopalan, N., \& Lakshmana Rao, P. Evaluation of a commercial Dengue NS1 enzyme-linked immunosorbent assay for early diagnosis of dengue infection. Indian J Med Microbiol.2011; 29(1): 51.

49. Mackenzie JM, Jones MK, Young PR. Immunolocalization of the dengue virus nonstructural glycoprotein NS1 suggests a role in viral RNA replication. Virology. 1996;220(1):232-40.

50. Kumarasamy V, Wahab AHA, Chua SK, Hassan Z, Chem YK, Mohamad M, et al. Evaluation of a commercial dengue NS1 antigen-capture ELISA for laboratory diagnosis of acute dengue virus infection. J Virol Methods. 2007;140(1-2):75-9.

51. Duyen HTL, Ngoc TV, Ha DT, Hang VTT, Kieu NTT, Young PR, et al. Kinetics of Plasma Viremia and Soluble Nonstructural Protein 1 Concentrations in Dengue: Differential Effects According to Serotype and Immune Status. J Infect Dis. 2011;203(9):1292-300.

52. Young PR, Hilditch PA, Bletchly C, Halloran W. An Antigen Capture Enzyme-Linked Immunosorbent Assay Reveals High Levels of the Dengue Virus Protein NS1 in the Sera of Infected Patients. J Clin Microbiol. 2000;38:1053-7. https://jcm.asm.org/content/38/3/1053. Accessed 3 Oct 2018.

53. Koraka P, Burghoorn-maas CP, Setiati TE, Djamiatun K, Groen J, Osterhaus ADME, et al. Detection of Immune-Complex-Dissociated Nonstructural-1 Antigen in Patients with Acute Dengue Virus Infections Detection of Immune-Complex-Dissociated Nonstructural-1 Antigen in Patients with Acute Dengue Virus Infections. J Clin Microbiol. 2003;41(9):4154-9.

54. Hunsperger EA, Yoksan S, Buchy P, Nguyen VC, Sekaran SD, Enria DA, et al. Evaluation of commercially available anti-dengue virus immunoglobulin $\mathrm{M}$ tests. Emerg Infect Dis. 2009;15(3):436-40.

55. Peeling RW, Artsob H, Pelegrino JL, Buchy P, Cardosa MJ, Devi S, et al. Evaluation of diagnostic tests: dengue. Nat Rev Microbiol. 2010;8(12):S30-7.

56. Priyamvada L, Hudson W, Ahmed R, Wrammert J. Humoral cross-reactivity between Zika and dengue viruses: implications for protection and pathology. Emerg Microbes Infect. 2017;6(5):e33.

57. Dejnirattisai W, Supasa P, Wongwiwat W, Rouvinski A, Barba-Spaeth G, Duangchinda T, et al. Dengue virus sero-cross-reactivity drives antibody-dependent enhancement of infection with Zika virus. Nat Immunol. 2016;17(9):1102-8.

58. Prince HE, Yeh C, Lapé-Nixon M. Utility of IgM/lgG ratio and igg avidity for distinguishing primary and secondary dengue virus infections using sera collected more than 30 days after disease onset. Clin 
Vaccine Immunol. 2011;18(11):1951-6.

59. Falconar AKI, Plata E de, Romero-Vivas CME. Altered Enzyme-Linked Immunosorbent Assay Immunoglobulin M (IgM)/IgG Optical Density Ratios Can Correctly Classify All Primary or Secondary Dengue Virus Infections 1 Day after the Onset of Symptoms, when All of the Viruses Can Be Isolated. Clin Vaccine Immunol. 2006;13(9):1044-51.

60. Geneva, Switzerland: World Health Organization; 2009. WHO. Dengue: Guidelines for Diagnosis, Treatment, Prevention and Control. Part 1.1.6: Dengue case classification; pp. 10-2.

61. Bhoopat L, Bhamarapravati N, Attasiri C, Yoksarn S, Chaiwun B, Khunamornpong S, et al. Immunohistochemical characterization of a new monoclonal antibody reactive with dengue virusinfected cells in frozen tissue using immunoperoxidase technique. Asian Pac J Allergy Immunol. 1996;14(12):107-13.

62. Hall WC, Crowell TP, Watts DM, Barros VL, Kruger H, Pinheiro F, et al. Demonstration of yellow fever and dengue antigens in formalin-fixed paraffin-embedded human liver by immunohistochemical analysis. Am J Trop Med Hyg. 1991;45(4):408-17.

63. Subedi D, Taylor-Robinson AW. Laboratory Diagnosis of Dengue Infection: Current Techniques and Future Strategies. Open J Clin Diagn. 2014;04(01):63-70.

64. Kao C-L, King C-C, Chao D-Y, Wu H-L, Chang G-JJ. Laboratory diagnosis of dengue virus infection: current and future perspectives in clinical diagnosis and public health. J Microbiol Immunol Infect Wei Mian Yu Gan Ran Za Zhi. 2005;38(5):5-16.

65. Endy TP, Nisalak A, Vaughn DW. Diagnosis of Dengue Virus Infections. In: Tropical Medicine: Science and Practice. Published by Imperial College Press and distributed by World Scientific Publishing Co.; 2008. p. 327-60.

66. Thomas SJ, Nisalak A, Anderson KB, Libraty DH, Kalayanarooj S, Vaughn DW, et al. Dengue plaque reduction neutralization test (PRNT) in primary and secondary dengue virus infections: How alterations in assay conditions impact performance. Am J Trop Med Hyg. 2009;81(5):825-33.

67. Maeda A, Maeda J. Review of diagnostic plaque reduction neutralization tests for flavivirus infection. Vet J. 2013;195(1):33-40.

68. Saxena P, Dash P, Santhosh S, Shrivastava A, Parida M, Rao P. Development and evaluation of one step single tube multiplex RT-PCR for rapid detection and typing of dengue viruses. Virol J. 2008;5(1):20.

69. Tan IL, Dimamay MPS, Buerano CC, Alfon JAR, Tanig CZ, Matias RR, et al. Development and evaluation of a fluorogenic real-time RT-PCR for the detection of dengue 3 virus. J Med Virol. 2010;82:2053-63.

70. Huhtamo E, Hasu E, Uzcátegui NY, Erra E, Nikkari S, Kantele A, et al. Early diagnosis of dengue in travelers: Comparison of a novel real-time RT-PCR, NS1 antigen detection and serology. J Clin Virol. 2010;47(1):49-53.

71. Waggoner JJ, Abeynayake J, Sahoo MK, Gresh L, Tellez Y, Gonzalez K, et al. Single-reaction, multiplex, real-time rt-PCR for the detection, quantitation, and serotyping of dengue viruses. PLoS 
Negl Trop Dis. 2013;7(4):e2116.

72. Sasmono RT, Aryati A, Wardhani P, Yohan B, Trimarsanto H, Fahri S, et al. Performance of Simplexa Dengue Molecular Assay Compared to Conventional and SYBR Green RT-PCR for Detection of Dengue Infection in Indonesia. PLoS ONE. 2014;9(8): e103815.

73. Alm E, Lindegren G, Falk KI, Lagerqvist N. One-step real-time RT-PCR assays for serotyping dengue virus in clinical samples. BMC Infect Dis. 2015;15.

74. Klungthong C, Manasatienkij W, Phonpakobsin T, Chinnawirotpisan P, Rodpradit P, Hussem K, et al. Monitoring and improving the sensitivity of dengue nested RT-PCR used in longitudinal surveillance in Thailand. J Clin Virol Off Publ Pan Am Soc Clin Virol. 2015;63:25-31.

75. Waggoner JJ, Sahadeo NSD, Brown A, Mohamed-Hadley A, Hadley D, Carrington L, et al. Improved Serotype-Specific Dengue Virus Detection in Trinidad and Tobago using a Multiplex, Real-Time RTPCR. Diagn Microbiol Infect Dis. 2015;81(2):105-6.

76. Chakravarti A, Chauhan MS, Banerjee S, Roy P. Comparison of multiplex RT-PCR and real-time HybProbe assay for serotyping of dengue virus using reference strains and clinical samples from India. Indian J Pathol Microbiol. 2016;59(3):330.

77. Kassim FM, Izati MN, TgRogayah T a. R, Apandi YM, Saat Z. Use of dengue NS1 antigen for early diagnosis of dengue virus infection. Southeast Asian J Trop Med Public Health. 2011;42(3):562-9.

78. Ahmed NH, Broor S. Comparison of NS1 antigen detection ELISA, real time RT-PCR and virus isolation for rapid diagnosis of dengue infection in acute phase. J Vector Borne Dis. 2014;6:194-199.

79. Mahapatra D, Sarangi G, Mahapatra A, Paty BP, Das P, Chayani N. NS1 Antigen Capture ELISA an Effective Method for Diagnosis of Early Dengue Infection - Report of an Outbreak at Angul District, Odisha, India. J Clin Diagn Res. 2014;8(8):DC08-DC10.

80. Anand AM, Sistla S, Dhodapkar R, Hamide A, Biswal N, Srinivasan B. Evaluation of NS1 Antigen Detection for Early Diagnosis of Dengue in a Tertiary Hospital in Southern India. J Clin Diagn Res. 2016;10(4):DC01-4.

81. Suleman M, Faryal R, Alam MM, Sharif S, Shaukat S, Aamir UB, et al. NS1 antigen: A new beam of light in the early diagnosis of dengue infection. Asian Pac J Trop Med. 2016;9(12):1212-4.

82. Ambrose JH, Sekaran SD, Azizan A. Dengue Virus NS1 Protein as a Diagnostic Marker: Commercially Available ELISA and Comparison to qRT-PCR and Serological Diagnostic Assays Currently Used by the State of Florida. J. Trop. Med. 2017;2017:6.

83. Hang VT, Nguyet NM, Trung DT, Tricou V, Yoksan S, Dung NM, et al. Diagnostic Accuracy of NS1 ELISA and Lateral Flow Rapid Tests for Dengue Sensitivity, Specificity and Relationship to Viraemia and Antibody Responses. PLoS Negl Trop Dis. 2009;3(1):e360.

84. Zainah S, Wahab AHA, Mariam M, Fauziah MK, Khairul AH, Roslina I, et al. Performance of a commercial rapid dengue NS1 antigen immunochromatography test with reference to dengue NS1 antigen-capture ELISA. J Virol Methods. 2009;155:157-60.

85. Anderson NW, Jespersen DJ, Rollins L, Seaton B, Prince HE, Theel ES. Detection of the dengue virus NS1 antigen using an enzyme immunoassay. Diagn Microbiol Infect Dis. 2014;79(2):194-7. 
86. Teoh B-T, Sam S-S, Tan K-K, Johari J, Abd-Jamil J, Hooi P-S, et al. The Use of NS1 Rapid Diagnostic Test and qRT-PCR to Complement IgM ELISA for Improved Dengue Diagnosis from Single Specimen. Sci Rep. 2016;6:27663.

87. Vongsouvath M, Phommasone K, Sengvilaipaseuth O, Kosoltanapiwat N, Chantratita N, Blacksell SD, et al. Using Rapid Diagnostic Tests as a Source of Viral RNA for Dengue Serotyping by RT-PCR - A Novel Epidemiological Tool. PLoS Negl Trop Dis. 2016;10(5): e0004704.

88. Shukla MK, Singh N, Sharma RK, Barde PV. Utility of dengue NS1 antigen rapid diagnostic test for use in difficult to reach areas and its comparison with dengue NS1 ELISA and qRT-PCR. J Med Virol. 2017;89(7):1146-50.

89. Pal S, Dauner AL, Valks A, Forshey BM, Long KC, Thaisomboonsuk B, et al. Multicountry Prospective Clinical Evaluation of Two Enzyme-Linked Immunosorbent Assays and Two Rapid Diagnostic Tests for Diagnosing Dengue Fever. J Clin Microbiol. 2015;53(4):1092-102.

90. Nunes MRT, Faria NR, de Vasconcelos JM, Golding N, Kraemer MU, de Oliveira LF, et al. Emergence and potential for spread of Chikungunya virus in Brazil. BMC Med. 2015;13(1):102.

91. Namekar M, Ellis EM, O'Connell M, Elm J, Gurary A, Park SY, et al. Evaluation of a New Commercially Available Immunoglobulin M Capture Enzyme-Linked Immunosorbent Assay for Diagnosis of Dengue Virus Infection. J Clin Microbiol. 2013;51(9):3102-6.

92. Welch RJ, Chang G-JJ, Litwin CM. Comparison of a commercial dengue IgM capture ELISA with dengue antigen focus reduction microneutralization test and the centers for disease control dengue IgM capture-ELISA. J Virol Methods. 2014;195:247-9.

93. Carter MJ, Emary KR, Moore CE, Parry CM, Sona S, Putchhat H, et al. Rapid Diagnostic Tests for Dengue Virus Infection in Febrile Cambodian Children: Diagnostic Accuracy and Incorporation into Diagnostic Algorithms. PLoS Negl Trop Dis. 2015;9(2): e0003424.

94. Mardekian SK, Roberts AL. Diagnostic options and challenges for dengue and chikungunya viruses. BioMed Res Int. 2015;2015:8.

95. Guzman MG, Jaenisch T, Gaczkowski R, Ty Hang VT, Sekaran SD, Kroeger A, et al. Multi-country evaluation of the sensitivity and specificity of two commercially-available NS1 ELISA assays for dengue diagnosis. PLoS Negl Trop Dis. 2010;4(8): e811.

96. Peh AEK, Leo Y-S, Toh CS. Current and nano-diagnostic tools for dengue infection. Front Biosci Sch Ed. 2011;3:806-21.

97. Kumbhat S, Sharma K, Gehlot R, Solanki A, Joshi V. Surface plasmon resonance based immunosensor for serological diagnosis of dengue virus infection. J Pharm Biomed Anal. 2010;52(2):255-9.

98. Neethirajan S, Ragavan V, Weng X, Chand R. Biosensors for Sustainable Food Engineering: Challenges and Perspectives. Biosensors. 2018;8(1):23.

99. Asal M, Özen Ö, Şahinler M, Polatoğlu İ. Recent Developments in Enzyme, DNA and Immuno-Based Biosensors. Sensors. 2018;18(6):1924. 
100. Parkash O, Shueb RH. Diagnosis of Dengue Infection Using Conventional and Biosensor Based Techniques. Viruses. 2015;7(10):5410-27.

101. Jahanshahi P, Zalnezhad E, Sekaran SD, Adikan FRM. Rapid Immunoglobulin M-Based Dengue Diagnostic Test Using Surface Plasmon Resonance Biosensor. Sci Rep. 2014;4:3851

102. Wong WR, Krupin O, Sekaran SD, Mahamd Adikan FR, Berini P. Serological diagnosis of dengue infection in blood plasma using long-range surface plasmon waveguides. Anal Chem. 2014;86:1735-43.

103. Oliveira N, Souza E, Ferreira D, Zanforlin D, Bezerra W, Borba MA, et al. A Sensitive and Selective Label-Free Electrochemical DNA Biosensor for the Detection of Specific Dengue Virus Serotype 3 Sequences. Sensors. 2015;15:15562-77.

104. Wasik D, Mulchandani A, Yates MV. Point-of-Use Nanobiosensor for Detection of Dengue Virus NS1 Antigen in Adult Aedes aegypti: A Potential Tool for Improved Dengue Surveillance. Anal Chem. 2018;90:679-84.

105. Ariffin EY, Tan LL, Abd. Karim NH, Yook Heng L. Optical DNA Biosensor Based on Square-Planar Ethyl Piperidine Substituted Nickel(II) Salphen Complex for Dengue Virus Detection. Sensors. 2018;18(4):1173.

106. Bumgarner R. Overview of DNA microarrays: types, applications, and their future. Curr Protoc Mol Biol. 2013;22:22.1.

107. Cretich M, Damin F, Chiari M. Protein microarray technology: how far off is routine diagnostics? The Analyst. 2014;139(3):528-42.

108. Díaz-Badillo A, de Lourdes Muñoz M, Perez-Ramirez G, Altuzar V, Burgueño J, Mendoza-Alvarez JG, et al. A DNA Microarray-Based Assay to Detect Dual Infection with Two Dengue Virus Serotypes. Sensors. 2014;14(5):7580-601.

109. Wang D, Zheng $Y$, Kang X, Zhang X, Hao H, Chen W, et al. A multiplex ELISA-based protein array for screening diagnostic antigens and diagnosis of Flaviviridae infection. Eur $\mathrm{J}$ Clin Microbiol Infect Dis 2015;34(7):1327-36.

110. Gaylord ST, Abdul-Aziz S, Walt DR. Single-Molecule Arrays for Ultrasensitive Detection of Host Immune Response to Dengue Virus Infection. J Clin Microbiol. 2015;53(5):1722-4.

111. Jayamohan H, Sant HJ, Gale BK. Applications of Microfluidics for Molecular Diagnostics. In: Jenkins G, Mansfield CD, editors. Microfluidic Diagnostics: Methods and Protocols. Totowa, NJ: Humana Press; 2013. p. 305-34.

112. Jayamohan H, Romanov V, Li H, Son J, Samuel R, Nelson J, et al. Advances in Microfluidics and Labon-a-Chip Technologies. In: Molecular Diagnostics. Elsevier; 2017. p. 197-217.

113. Aeinehvand MM, Ibrahim F, Harun SW, Djordjevic I, Hosseini S, Rothan HA, et al. Biosensing enhancement of dengue virus using microballoon mixers on centrifugal microfluidic platforms. Biosens Bioelectron. 2015;67:424-30.

114. Hosseini S, Aeinehvand MM, Uddin SM, Benzina A, Rothan HA, Yusof R, et al. Microsphere integrated microfluidic disk: synergy of two techniques for rapid and ultrasensitive dengue detection. Sci Rep. 
2015;5:16485.

115. Greenberg AS, Avila D, Hughes M, Hughes A, McKinney EC, Flajnik MF. A new antigen receptor gene family that undergoes rearrangement and extensive somatic diversification in sharks. Nature. 1995;374(6518):168.

116. Hamers-Casterman C, Atarhouch T, Muyldermans S, Robinson G, Hammers C, Songa EB, et al. Naturally occurring antibodies devoid of light chains. Nature. 1993;363(6428):446.

117. Genst ED, Silence K, Decanniere K, Conrath K, Loris R, Kinne J, et al. Molecular basis for the preferential cleft recognition by dromedary heavy-chain antibodies. Proc Natl Acad Sci. 2006;103(12):4586-91.

118. Conrath KE, Wernery U, Muyldermans S, Nguyen VK. Emergence and evolution of functional heavychain antibodies in Camelidae. Dev Comp Immunol. 2003;27(2):87-103.

119. Muyldermans S. Single-domain camel antibodies: current status. J Biotechnol. 2001;74:277-302. http://dx.doi.org/10.1016/S1389-0352(01)00021-6.

120. Harmsen MM, De Haard HJ. Properties, production, and applications of camelid single-domain antibody fragments. Appl Microbiol Biotechnol. 2007;77(3):13-22.

121. Desmyter A, Transue T, Arbabi-Ghahroudi M, Thi M-HD, Poortmans F, Hamers-Casterman, et al. Crystal structure of a camel single-domain $\mathrm{VH}$ antibody fragment in complex with lysozyme. Nat Struct Biol. 1996;3(9):284-9.

122. Ewert S, Cambillau C, Conrath K, Plückthun A. Biophysical Properties of Camelid V HH Domains Compared to those of Human V H 3 Domains. Biochemistry. 2002;41(11):3628-36.

123. van der Linden RH, de Geus B, Frenken GJ, Peters H, Verrips CT. Improved production and function of Ilama heavy chain antibody fragments by molecular evolution. J Biotechnol. 2000;80:261-70.

124. Odongo S, Sterckx YGJ, Stijlemans B, Pillay D, Baltz T, Muyldermans S, et al. An Anti-proteome Nanobody Library Approach Yields a Specific Immunoassay for Trypanosoma congolense Diagnosis Targeting Glycosomal Aldolase. PLoS Negl Trop Dis. 2016;10(2):1-24.

125. Deckers N, Saerens D, Kanobana K, Conrath K, Victor B, Wernery U, et al. Nanobodies, a promising tool for species-specific diagnosis of Taenia solium cysticercosis. Int J Parasitol. 2009;39:625-33.

126. Fatima A, Wang H, Kang K, Xia L, Wang Y, Ye W, et al. Development of VHH antibodies against dengue virus type 2 NS1 and comparison with monoclonal antibodies for use in immunological diagnosis. PLoS One. 2014;9(4):e95263.

127. Shriver-Lake LC, Goldman ER, Zabetakis D, Anderson GP. Improved production of single domain antibodies with two disulfide bonds by co-expression of chaperone proteins in the Escherichia coli periplasm. J Immunol Methods. 2017;443:64-7.

128. Wilder-Smith A, Gubler DJ, Weaver SC, Monath TP, Heymann DL, Scott TW. Epidemic arboviral diseases: priorities for research and public health. Lancet Infect Dis. 2017;17: e101-6.

\section{Tables}


Table 1: Articles that reported different dengue laboratory diagnoses $(n=51) *$

\begin{tabular}{ll}
\hline \multicolumn{1}{c}{ Diagnostic test } & \multicolumn{1}{c}{ Ref } \\
\hline Dengue virus isolation & {$[29],[30]$} \\
RT-PCR & {$[33],[34],[35],[36],[37],[38],[39],[68],[69],[70],[71],[72],[73],[74,[75]$} \\
& {$[76]$} \\
\hline RT-LAMP & {$[40],[41]$} \\
\hline NSBA & {$[44],[45]$} \\
\hline RT-RPA & {$[47]$} \\
\hline NS1 ELISA & {$[50],[52],[53],[77],[78],[79],[80],[81]$ and $[82]$} \\
\hline NS1 RDT & {$[83],[84],[85],[86],[87]$ and $[88]$} \\
\hline IgM ELISA & {$[54],[89],[91]$, and $[92]$} \\
\hline IgG ELISA & {$[56],[57]$} \\
\hline IgM/IgG seroconversion & {$[58],[59]$} \\
\hline Haemagglutination & {$[60]$} \\
test & {$[66],[67]$} \\
\hline PRNT & {$[61],[62]$} \\
\hline Immunohistochemitry &
\end{tabular}

*Source of data: PubMed, Web of Science and Google Scholar databases. 
Table 2: Sensitivity and specificity of selected dengue laboratory diagnostic tests computed from literature

(2008-2017, $\mathrm{n}=28$ studies)*

\begin{tabular}{|c|c|c|c|c|c|c|c|c|}
\hline & Diagnostic t & test & $\begin{array}{l}\text { Reference } \\
\text { standard }\end{array}$ & Study design & $\begin{array}{l}\text { Sample } \\
\text { size }\end{array}$ & $\begin{array}{l}\text { Sensitivity } \\
(95 \% \mathrm{CI})\end{array}$ & $\begin{array}{l}\text { Specificity } \\
(95 \% \mathrm{CI})\end{array}$ & Ref \\
\hline 1 & $\begin{array}{l}\text { Nested } \\
\text { PCR }\end{array}$ & RT- & NS1 Ag RDT & Prospective & 71 & $99.2(92.8-99.9)$ & $95.0(65.5-99.5)$ & {$[33]$} \\
\hline 2 & rRT-PCR & & $\begin{array}{l}\text { Sanger } \\
\text { sequencing }\end{array}$ & Prospective & 86 & 96.9 (87.8-99.3) & 98.7 (88.8-99.9) & [35] \\
\hline 3 & $\begin{array}{l}\text { Multiplex } \\
\text { PCR }\end{array}$ & RT- & Virus isolation & Retrospective & 620 & 99.5 (95.5-99.9) & 99.9 (99.1-100) & [68] \\
\hline 4 & RT-PCR & & RT-PCR & Retrospective & 42 & $93.5(76-98.5)$ & $97.6(80.8-99.8)$ & [69] \\
\hline 5 & rRT-PCR & & NS1 RDT & Retrospective & 97 & $82.6(71.7-89.9)$ & $86.4(70.9-94.3)$ & [70] \\
\hline 6 & rRT-PCR & & Nested RT-PCR & Retrospective & 74 & 99.3 (93.5-99.9) & $58.3(24.1-86.1)$ & [71] \\
\hline 7 & rRT-PCR & & RT-PCR & Retrospective & 184 & $99.6(96.7-100)$ & $98.9(90.0-99.9)$ & {$[72]$} \\
\hline 8 & RT-PCR & & rRT-PCR & Prospective & 85 & 93.8 (85.8-97.5) & $97.2(78.1-99.7)$ & [73] \\
\hline 9 & $\begin{array}{l}\text { Nested } \\
\text { PCR }\end{array}$ & RT- & IgM ELISA & Retrospective & 87 & $\begin{array}{l}87.0 \\
94.0)\end{array}$ & $100(76.0-100)$ & {$[74]$} \\
\hline 10 & rRT-PCR & & Nested RT-PCR & Retrospective & 182 & $90.5(80.3-95.7)$ & $75.8(67.6-82.4)$ & {$[75]$} \\
\hline 11 & $\begin{array}{l}\text { rHybProbe } \\
\text { PCR }\end{array}$ & & RT-PCR & Retrospective & 79 & 96.7 (86.8-99.2) & 98.6 (88.0-99.9) & {$[76]$} \\
\hline 12 & NS1 ELISA & & RT-PCR & Prospective & 208 & $53.7(42.9-64.1)$ & $81.0(73.4-86.8)$ & [77] \\
\hline 13 & NS1 ELISA & & rRT-PCR & Prospective & 150 & 81.7 (69.2-89.9) & $91.5(84.4-95.5)$ & [78] \\
\hline 14 & NS1 ELISA & & MAC-ELISA & Prospective & 92 & $60.6(47.0-72.7)$ & $34.5(22.0-49.6)$ & [79] \\
\hline 15 & NS1 ELISA & & RT-PCR & Prospective & 94 & $96.2(88.4-98.8)$ & $53.2(36.3-69.4)$ & {$[80]$} \\
\hline 16 & NS1 ELISA & & rRT-PCR & Retrospective & 1270 & 73.5 (69.0-75.7) & $46.2(42.3-50.2)$ & [81] \\
\hline 17 & NS1 ELISA & & qRT-PCR & Retrospective & 21 & $63.3(38.6-82.5)$ & $93.8(59.8-99.3)$ & {$[82]$} \\
\hline 18 & NS1 RDT & & NS1 ELISA & Retrospective & 125 & 99.5 (95.0-99.9) & 98.6 (87.8-99.9) & [83] \\
\hline 19 & NS1 RDT & & RT-PCR & Retrospective & 155 & $69.4(61.3-76.5)$ & $75.0(57.9-89.3)$ & {$[84]$} \\
\hline 20 & NS1 RDT & & RT-PCR & Prospective & 75 & $94.2(78.4-98.7)$ & $85.3(73.1-92.5)$ & {$[85]$} \\
\hline 21 & NS1 RDT & & IgM ELISA & Retrospective & 375 & $49.7(42.8-56.7)$ & $63.8(56.6-70.5)$ & {$[86]$} \\
\hline 22 & NS1 RDT & & RT-PCR & Prospective & 99 & $84.7(72.1-92.2)$ & 97.1 (88.4-99.3) & [87] \\
\hline 23 & NS1 RDT & & IgM ELISA & Retrospective & 249 & $99.6(96.3-100)$ & $97.2(92.6-99.0)$ & [88] \\
\hline 24 & IgM ELISA & & Virus isolation & Prospective & 863 & $94.7(90.1-97.2)$ & $80.3(77.2-83.1)$ & [89] \\
\hline 25 & IgM RDT & & MAC-ELISA & Retrospective & 400 & $92.8(88.4-95.6)$ & $97.8(94.7-99.1)$ & [90] \\
\hline 26 & IgM ELISA & & MAC-ELISA & Retrospective & 74 & 97.8 (82.2-99.8) & 99.0 (91.3-99.9) & [91] \\
\hline 27 & IgM ELISA & & PRNT & Retrospective & 1250 & $88.2(78.7-93.8)$ & $52.8(31.3-73.2)$ & {$[92]$} \\
\hline 28 & $\operatorname{IgM} \mathrm{RDT}$ & & IgM ELISA & Retrospective & 324 & $30.0(19.5-43.1)$ & $87.6(83.2-91.0)$ & [93] \\
\hline
\end{tabular}

*Source of data: PubMed, Web of Science and Google Scholar databases. 
Table 3: An overview of emerging diagnostic technologies for dengue virus infection (20014-2018, n=10 studies)*

\begin{tabular}{|c|c|c|c|c|c|c|c|c|}
\hline & \multirow[t]{2}{*}{ Technology } & \multirow[t]{2}{*}{$\begin{array}{l}\text { Reference } \\
\text { standard }\end{array}$} & \multirow[t]{2}{*}{ Biomarker } & \multirow[t]{2}{*}{ Sample type } & \multirow[t]{2}{*}{$\begin{array}{l}\text { Limit of } \\
\text { detection }\end{array}$} & \multicolumn{2}{|c|}{$\begin{array}{l}\text { Proposed } \\
\text { application }\end{array}$} & \multirow[t]{2}{*}{ Ref } \\
\hline & & & & & & Multiplex & $\mathrm{POC}$ & \\
\hline 1 & SPR biosensor & IgM ELISA & $\operatorname{IgM}$ & serum & NA & Yes & Yes & [101] \\
\hline 2 & LRSPP biosensor & IgM ELISA & $\operatorname{IgM}$ & plasma & $\begin{array}{l}\sim 12 \\
\mathrm{pg} / \mathrm{mm}^{2}\end{array}$ & No & Yes & [102] \\
\hline 3 & Biosensor & NA & cDNA & $\begin{array}{l}\text { spiked } \\
\text { serum }\end{array}$ & $3.09 \mathrm{nM}$ & Yes & Yes & [103] \\
\hline 4 & Immunosensor & NS1 ELISA & NS1 & saliva & $1 \mathrm{ng} / \mathrm{mL}$ & No & Yes & {$[104]$} \\
\hline 5 & Biosensor & NS1 ELISA & cDNA & $\begin{array}{l}\text { spiked } \\
\text { saliva/urine }\end{array}$ & $0.2 \mathrm{nM}$ & No & Yes & [105] \\
\hline 6 & Microarray & qRT-PCR & cDNA & serum & $\begin{array}{l}0.05- \\
0.2 \mathrm{ng} / \mathrm{spot}\end{array}$ & Yes & No & [108] \\
\hline 7 & Single-molecule Array & IgM ELISA & $\operatorname{IgM}$ & plasma & $\begin{array}{l}\text { X1000- } \\
10000 \text { fold }\end{array}$ & No & No & [109] \\
\hline 8 & ELISA-based array & IgM ELISA & EDIII & serum & X4-fold & Yes & No & {$[110]$} \\
\hline 9 & $\begin{array}{l}\text { Centrifugal } \\
\text { microfluidic }\end{array}$ & NS1 ELISA & NS1 & serum & $\begin{array}{l}3.54 \\
\mathrm{pfu} / \mathrm{mL}\end{array}$ & No & Yes & [113] \\
\hline 10 & $\begin{array}{l}\text { Microsphere-based } \\
\text { microfluidic disk }\end{array}$ & $\begin{array}{l}\text { Sandwich } \\
\text { ELISA }\end{array}$ & DENV & cell lysates & $1.9 \mathrm{pfu} / \mathrm{mL}$ & No & Yes & {$[114]$} \\
\hline
\end{tabular}

*Source of data: PubMed, Web of Science and Google Scholar.

\section{Figures}




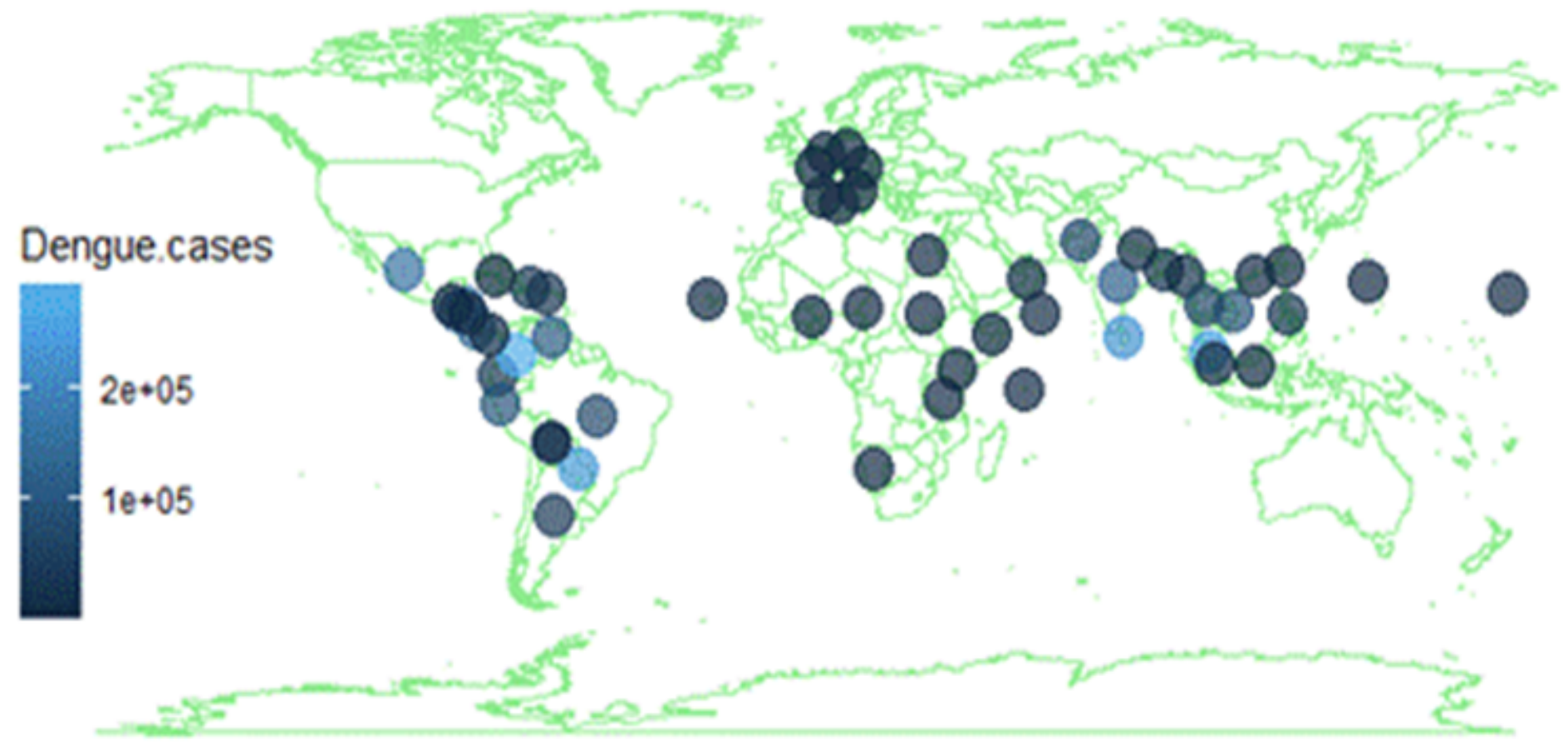

Figure 1

Global distribution of dengue cases reported between 2008 and 2018 based on the data (not shown) extracted from the global electronic reporting system for disease outbreaks (ProMed-mail) and WHO disease outbreak news (DONs). The light blue dots indicate countries with over 200,000 cases of Dengue and black dots represent countries with $<100,000$ cases. 


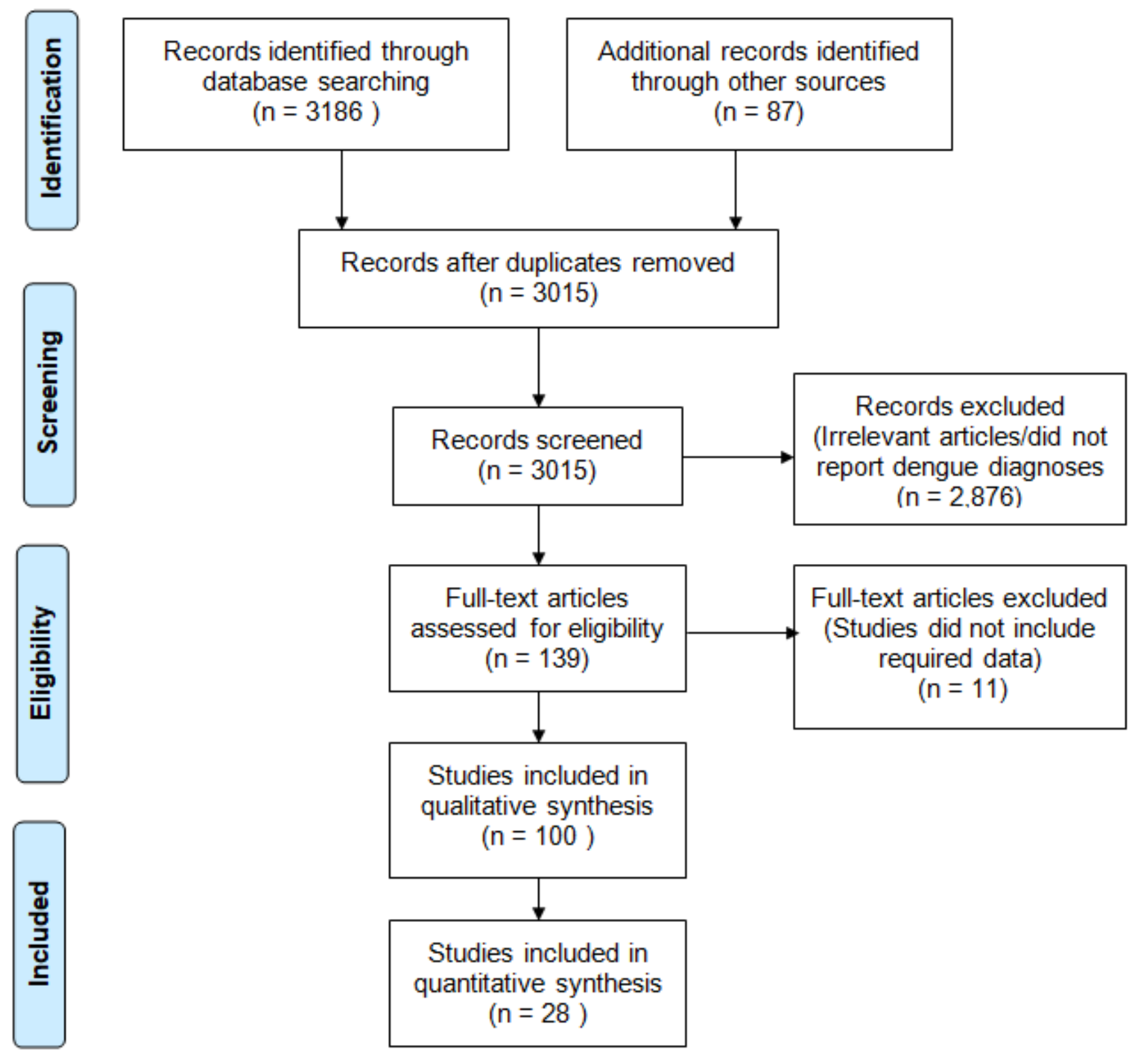

Figure 2

PRISMA flow diagram indicating the literature search and article selection process.

\section{Supplementary Files}

This is a list of supplementary files associated with this preprint. Click to download.

- S1PRISMA2009checklist.rtf

- S3Rsoftwarescriptssensitivityspecificitydata.txt

- S2PubMEDsearchstrategy.ttf 